УДК 663.252

DOI 10.30679/2219-5335-2019-3-57-169-181

ИЗМЕНЕНИЕ

ФИЗИКО-ХИМИЧЕСКОГО

СОСТАВА ВИН

ПОД ДЕЙСТВИЕМ НИЗИНА

Антоненко Михаил Викторович

канд. техн. наук

ст. научный сотрудник

НЦ «Виноделие»

e-mail: antonenko84@bk.ru

Гугучкина Татьяна Ивановна

д-р с.-х. наук, профессор

заведующая НЦ «Виноделие»

Марковский Михаил Григорьевич

канд. техн. наук

старший научный сотрудник

НЦ «Виноделие»

Абакумова Алла Андреевна

мл. научный сотрудник

НЦ «Виноделие»

Антоненко Ольга Павловна

канд. техн. наук

научный сотрудник

НЦ «Виноделие»

Федеральное государственное бюджетное научное учреждение «Северо-Кавказский федеральный научный иентр садоводства, виноградарства, виноделия», Краснодар, Россия

Получены новые знания о закономерностях изменения физикохимических и органолептических показателей винодельческой продукции в присутствии консерванта микробиального происхождения низина (пищевая добавка Е234), которые станут Основой для технологического обоснования проведения дополнительных обработок
UDC 663.252

DOI 10.30679/2219-5335-2019-3-57-169-181

\section{CHANGE OF PHYSICAL AND CHEMICAL COMPOSITION OF WINES UNDER THE NIZIN ACTION}

\author{
Antonenko Mikhail Victorovich \\ Cand. Tech. Sci. \\ Senior Research Associate \\ of CS «Wine-making» \\ e-mail: antonenko84@bk.ru
}

Guguchkina Tatyana Ivanovna

Dr. Sci. Agr., Professor

Head of SC «Wine-making»

Markovskiy Mikhail Grigorievich

Cand. Tech. Sci.

Senior Research Associate

of CS «Wine-making»

Abakumova Alla Andreyevna
Junior Research Associate
of CS «Wine-making»

Antonenko Olga Pavlovna

Cand. Tech. Sci.

Research Associate

of CS «Wine-making»

Federal State Budget

Scientific Institution

"North Caucasian Federal

Scientific Center of Horticulture,

Viticulture, Wine-making»,

Krasnodar, Russia

New knowledge was obtained about the conformity to natural lows of changes in physicochemical and organoleptic indicators of wine production in the presence of a preservation of microbial origin of nisin (food supplement E234), which will become the basis for the technological foundation 
виноматериалов сорбентами в целях повышения их потребительской безопасности и качества. В процессе исследования установлено, что в экспериментальных образцах вина с добавлением низина все анализируемые показатели (объёмная доля этилового спирта, массовая концентрация сахаров, массовая концентрация титруемых кислот в пересчёте на винную кислоту, массовая концентрация летучих кислот в пересчёте на уксусную кислоту, массовая концентрация приведённого экстракта, массовая концентрация лимонной кислоты, массовая концентрация общего диоксида серы, органических кислот, фенольных соединений, в том числе антоцианов для красных вин) физико-химического состава оставались без изменений и находились на одном уровне с аналогичными показателями контроля. Проведённые исследования белых и красных вин с добавлением низина показали, что в процессе выдержки происходили типичные окислительно-восстановительные процессы, характерные для процесса выдержки вина. Наиболее существенным было изменение массовой концентрации органических кислот, которые влияют главным образом на вкус и, соответственно, на качество вина. В результате анализа экспериментальных данных установлено, что контрольные и опытные образцы имели одинаковые органолептические характеристики и дегустационный балл. Вино столовое сухое белое имело соломенный цвет; чистый винный аромат с цветочными оттенками, соответствующий типу; полный, гармоничный, свежий вкус, без посторонних оттенков.

Ключевые слова: ВИНА СТОЛОВЫЕ БЕЛЫЕ И КРАСНЫЕ, АНТИБИОТИКИ, НИЗИН, ПОТРЕБИТЕЛЬСКАЯ БЕЗОПАСНОСТЬ, КАПИЛЛЯРНЫЙ ЭЛЕКТРОФОРЕЗ, ОРГАНИЧЕСКИЕ КИСЛОТЫ of additional processing of sorbents for wine materials aimed to increasing in their consumer safety and quality. It was established in the process of research that in the experimental samples of wine with the addition of nisin all analyzed parameters ( volume fraction of ethyl alcohol, mass concentration of sugars, mass concentration of titrated acids in terms of tartaric acid, mass concentration of volatile acids in terms of acetic acid, mass concentration of the above extract, mass concentration of citric acid, mass concentration of total sulfur dioxide, organic acids, phenolic compounds, including anthocyanins for red wines) the physical-chemical composition of the test samples of wines remained unchanged, and remained at the same level as in the control samples. Study carried out of white and red wines with the addition of nisin showed that during the aging the typical oxidation-reduction processes are occurred typical to the wine aging process. The most significant was the change in the mass concentration of organic acids, which mainly affects the taste and, consequently, the quality of the wine. As a result of the analysis of experimental data, it was established that the control and testing samples had the same organoleptic characteristics and tasting score. Dry white table wine has a straw color, pure wine aroma with flower shades, corresponding to wine type; full harmonious fresh taste, without extraneous shades.

Key words: RED AND WHITE TABLE WINES, ANTIBIOTICS, NISIN, CONSUMER SAFETY, CAPILLARY ELECTROPHORESIS, ORGANIC ACIDS 
Введение. Одним из важных направлений развития сектора пищевых биотехнологий в России является повышение продовольственной безопасности страны. Согласно Комплексной программе развития биотехнологий в Российской Федерации за прошедшие 20 лет в мире созданы принципиально новые биотехнологии и продукты, а производство ранее известных существенно оптимизировано. В итоге более 80 \% биотехнологической продукции, которая потребляется в России, является импортом [1].

Контроль качества винодельческой продукции должен осуществляться согласно нормативной документации, в которой отражены требования к безопасности. На межгосударственном уровне в первую очередь к такой документации относится Технический Регламент Таможенного Союза 021/2011 «О безопасности пищевой продукции», а также Технический Регламент Таможенного Союза № 029/2012 «Требования безопасности пищевых добавок, ароматизаторов и технологических вспомогательных средств» и др. [2, 3].

Имеются реальные факты обнаружения остаточных количеств антибиотиков в винах в европейских странах [4-8], где уделяется особое внимание контролю за качественным и количественным содержанием в вине и виноматериалах антибиотиков, к которым относят вещества, способные препятствовать порче винодельческой продукции или потере потребительских свойств из-за развития вредных микроорганизмов.

В настоящее время в России роль различных пищевых добавок, в том числе консервантов микробиального происхождения, имеющих потенциал для применения в виноделии, практически не выяснена [9-13]. При этом в некоторых странах низин (Е234) может быть использован для контроля микробиологического состояния при производстве вина (контроль яблочно-молочного брожения), а также биоконсервации в целях снижения уровня использования диоксида серы $[6,14,15]$.

В Российской Федерации препарат низин является консервантом (Е234), разрешённым для применения при производстве пищевой продук- 
ции. Технологические свойства низина в основном используются при изготовлении сыров, яйцепродуктов и пудингов, при этом строго нормируется его максимальный уровень в продукции.

Сотрудниками научного центра «Виноделие» Федерального государственного бюджетного научного учреждения «Северо-Кавказский федеральный научный центр садоводства, виноградарства, виноделия» разработаны эффективные методики по определению массовой концентрации консервантов (антибиотиков микробиального происхождения) в винодельческой продукции с использованием метода высокоэффективного капиллярного электрофореза, которые позволят производителям и потребителям проводить технологический контроль остаточных количеств натамицина и низина, что будет способствовать повышению безопасности выпускаемой продукции [9-16].

Сегодня возможности капиллярного электрофореза привлекают внимание многих учёных при создании методик исследования фруктовых соков, кофе и чая, а также вина и других алкогольных напитков [17-20]. Однако в результате анализа литературы в области оценки качества и безопасности виноградных вин установлено, что практически отсутствуют сведения о закономерностях изменения физико-химического состава вина при взаимодействии с антибиотиками [14-15]. Перечисленные факторы отражают интерес технологов и специалистов винодельческой отрасли к качеству и потребительской безопасности получаемой продукции, в связи с этим работа своевременна и актуальна.

Новизна исследований заключается в получении новых знаний об основных закономерностях формирования химического состава винодельческой продукции в присутствии пищевых добавок.

\section{Задачи исследований:}

- выявить влияние присутствия низина на физико-химический состав виноградных вин (объёмная доля этилового спирта, массовые концентрации 
Плодоводство и виноградарство Юга России № 57(03), 2019 г.

титруемых кислот, летучих кислот, органических кислот, фенольных соединений, в том числе красящих веществ для красных вин);

- выявить влияние присутствия низина на органолептические показатели виноградных вин (внешний вид, цвет, аромат и вкус);

- установить закономерности формирования химического состава винодельческой продукции в присутствии пищевых добавок.

Объекты и методы исследований. Исследования выполнялись на базе научного центра «Виноделие» и центра коллективного пользования «Приборно-аналитический» ФГБНУ СКФНЦСВВ с использованием общепринятых и действующих на территории РФ стандартов, а также оригинальных методик с привлечением капиллярного электрофореза. Основные компоненты химического состава виноматериалов - объёмную долю этилового спирта; массовую концентрацию сахаров, тируемых и летучих кислот, приведённого экстракта, диоксида серы, а также органолептический анализ вин проводили по методикам действующих национальных (ГОСТ Р) и межгосударственных стандартов (ГОСТ).

Органические кислоты определяли методом высокоэффективного капиллярного электрофореза на приборе «Капель 105» по методике, разработанной в научном центре «Виноделие» ФГБНУ СКФНЦСВВ [21]. Органолептические свойства столовых вин (внешний вид, аромат и вкус) определялись дегустационной комиссией ФГБНУ СКФНЦСВВ на соответствие требованиям ГОСТ 32030-2013 «Вина столовые и виноматериалы столовые. Общие технические условия», в том числе ГОСТ 32051-2013 «Продукция винодельческая. Методы органолептического анализа».

В качестве объектов исследований служили красные и белые столовые виноградные вина, в которые искусственно вносился низин (Е234), в соответствии с перечнем пищевых добавок, разрешённых для применения при 
Плодоводство и виноградарство Юга России № 57(03), 2019 г.

производстве пищевой продукции. Исходные вина, выработанные предприятиями Краснодарского края, по содержанию всех основных компонентов химического состава соответствовали нормам и показателям качества.

Обсужнение результатов. В связи со значительным импортом в Россию сырья и вспомогательных материалов для винодельческого производства, а также использованием антибиотиков в ряде зарубежных стран, считаем, что выявление закономерностей изменения внешнего вида, физико-химического состава и органолептических показателей вин под действием пищевых добавок является актуальной и своевременной задачей. Полученные результаты будут служить основой при обосновании и разработке технологических приёмов удаления остаточных количеств антибиотиков из виноматериалов и вин.

В процессе проводимых экспериментов обеспечивались условия, исключающие любое влияние внешних факторов - света, кислорода воздуха или изменения температуры, при которых образцы хранились при температуре $20 \pm 2{ }^{\circ} \mathrm{C}$, в плотно закрытых полностью налитых бутылках, в тёмном месте.

Важным технологическим условием применения консервантов и антибиотиков при производстве пищевой продукции является их нейтральное влияние на вкус и аромат, однако исследования по изучению влияния низина на химический состав белых и красных вин ранее практически не выполнялись.

В соответствии с целью работы и задачами исследований изучена реакция основного состава вина на присутствие в нем консерванта низина (E234), для этого в вина вносились пищевая добавка «Низин» с содержанием действующего вещества 2,5\%.

Для определения степени изменения концентраций основных компонентов вина были взяты контрольные вина, без добавления консерванта Е-234 низин, затем по истечении 2-х, 4-х, 8-ми и 12-ти недель контрольные и экспериментальные образцы анализировали по основным показателям качества (табл. 1, 2). 
Плодоводство и виноградарство Юга России № 57(03), 2019 г.

Таблица 1 - Изменение физико-химических показателей белого вина в ходе выдержки в присутствии низина

\begin{tabular}{|c|c|c|c|c|c|c|c|c|c|}
\hline \multirow{2}{*}{ Показатель } & \multirow{2}{*}{$\begin{array}{c}\text { Исходное } \\
\text { вино }\end{array}$} & \multicolumn{4}{|c|}{ Контроль } & \multicolumn{4}{|c|}{ С добавкой низина } \\
\hline & & 2 нед. & 4 нед. & 8 нед. & 12 нед. & 2 нед. & 4 нед. & 8 нед. & 12 нед. \\
\hline Спирт, \% об. & 11,15 & 11,12 & 11,16 & 11,15 & 11,14 & 11,16 & 11,14 & 11,12 & 11,16 \\
\hline $\begin{array}{l}\text { Титруемая } \\
\text { кислотность, } \\
\text { г/дм }{ }^{3}\end{array}$ & 7,25 & 7,20 & 7,15 & 7,06 & 7,02 & 7,21 & 7,18 & 7,08 & 7,00 \\
\hline $\begin{array}{l}\text { Летучая } \\
\text { кислотность, } \\
\text { г/дм }\end{array}$ & 0,49 & 0,47 & 0,50 & 0,48 & 0,50 & 0,48 & 0,49 & 0,48 & 0,51 \\
\hline $\mathrm{SO}_{2} \mathrm{мг} /$ дм $^{3}$ & 122 & 118 & 116 & 110 & 107 & 120 & 117 & 109 & 107 \\
\hline $\begin{array}{l}\text { Восст. caxapa, } \\
\Gamma / \text { дм }^{3}\end{array}$ & 1,4 & 1,3 & 1,3 & 1,4 & 1,4 & 1,4 & 1,5 & 1,4 & 1,3 \\
\hline $\begin{array}{l}\text { Экстракт, } \\
\text { г/дм }{ }^{3}\end{array}$ & 18,9 & 18,7 & 18,5 & 18,1 & 17,7 & 18,5 & 18,3 & 17,9 & 17,5 \\
\hline $\mathrm{pH}$ & 3,05 & 3,05 & 3,06 & 3,08 & 3,10 & 3,04 & 3,05 & 3,08 & 3,11 \\
\hline $\begin{array}{l}\text { Винная к-та, } \\
\Gamma / \text { дм }^{3}\end{array}$ & 2,85 & 2,83 & 2,80 & 2,65 & 2,47 & 2,81 & 2,84 & 2,62 & 2,46 \\
\hline $\begin{array}{l}\text { Яблочная к-та, } \\
\text { г/дм }\end{array}$ & 1,50 & 1,50 & 1,45 & 1,47 & 1,44 & 1,54 & 1,47 & 1,49 & 1,48 \\
\hline $\begin{array}{l}\text { Янтарная к-та, } \\
\text { г/дм }\end{array}$ & 0,42 & 0,41 & 0,43 & 0,40 & 0,39 & 0,42 & 0,41 & 0,42 & 0,40 \\
\hline $\begin{array}{l}\text { Лимонная к-та, } \\
\text { г/дм }\end{array}$ & 0,24 & 0,22 & 0,23 & 0,23 & 0,22 & 0,23 & 0,23 & 0,22 & 0,20 \\
\hline $\begin{array}{l}\text { Уксусная к-та, } \\
\text { г/дм }\end{array}$ & 0,43 & 0,43 & 0,44 & 0,44 & 0,46 & 0,44 & 0,44 & 0,45 & 0,45 \\
\hline $\begin{array}{l}\text { Молочная к-та, } \\
\text { г/дм }\end{array}$ & 1,95 & 1,91 & 1,96 & 1,98 & 2,00 & 1,95 & 1,92 & 1,99 & 1,97 \\
\hline $\begin{array}{l}\text { Сумма } \\
\text { органических } \\
\text { кислот, г/дм }\end{array}$ & 7,39 & 7,30 & 7,31 & 7,17 & 6,98 & 7,39 & 7,31 & 7,19 & 6,96 \\
\hline
\end{tabular}

Проведённые исследования белых и красных вин с добавлением низина показали, что в процессе выдержки происходили типичные окислительновосстановительные процессы, характерные для выдержки вина. Установлено, что наиболее существенным было изменение массовой концентрации 
Плодоводство и виноградарство Юга России № 57(03), 2019 г.

органических кислот, которые влияют главным образом на вкус и, соответственно, на качество вина (см. табл. 2).

Таблица 2 - Изменение физико-химических показателей красного вина в ходе выдержки в присутствии низина

\begin{tabular}{|c|c|c|c|c|c|c|c|c|c|}
\hline \multirow{2}{*}{ Показатель } & \multirow{2}{*}{$\begin{array}{c}\text { Исходное } \\
\text { вино }\end{array}$} & \multicolumn{4}{|c|}{ Контроль } & \multicolumn{4}{|c|}{ С добавкой низина } \\
\hline & & 2 нед. & 4 нед. & 8 нед. & 12 нед. & 2 нед. & 4 нед. & 8 нед. & 12 нед. \\
\hline Спирт, \% & 13,15 & 13,14 & 13,1 & 13,14 & 13,15 & 13,16 & 13,12 & 13,17 & 13,12 \\
\hline $\begin{array}{l}\text { Титруемая } \\
\text { кислотность, } \\
\text { г/дм }\end{array}$ & 5,76 & 5,76 & 5,7 & 5,69 & 5,64 & 5,78 & 5,75 & 5,72 & 5,68 \\
\hline $\begin{array}{l}\text { Летучая } \\
\text { кислотность, } \\
\text { г/дм }{ }^{3}\end{array}$ & 0,42 & 0,44 & 0,46 & 0,43 & 0,47 & 0,47 & 0,47 & 0,46 & 0,48 \\
\hline $\mathrm{SO}_{2} \mathrm{M \Gamma} /$ дм$^{3}$ & 73,9 & 64,5 & 62,4 & 61,9 & 58,9 & 65,6 & 64,9 & 61,6 & 58,8 \\
\hline $\begin{array}{l}\text { Восст. caxapa, } \\
\Gamma / \text { дм }^{3}\end{array}$ & 2,0 & 1,9 & 2,0 & 2,0 & 2,0 & 1,9 & 2,0 & 2,0 & 1,9 \\
\hline $\begin{array}{l}\text { Экстракт, } \\
\text { г/дм }{ }^{3}\end{array}$ & 26,9 & 26,2 & 25,8 & 26,1 & 25,7 & 26,4 & 26 & 25,7 & 25,8 \\
\hline $\mathrm{pH}$ & 3,48 & 3,49 & 3,48 & 3,5 & 3,49 & 3,48 & 3,49 & 3,49 & 3,49 \\
\hline $\begin{array}{l}\text { Винная к-та, } \\
\Gamma / \text { д }^{3}\end{array}$ & 1,6 & 1,49 & 1,55 & 1,54 & 1,45 & 1,6 & 1,59 & 1,49 & 1,5 \\
\hline $\begin{array}{l}\text { Яблочная } \\
\text { к-та, г/дм }\end{array}$ & 2,00 & 1,92 & 1,92 & 1,84 & 1,97 & 1,93 & 1,99 & 1,94 & 1,87 \\
\hline $\begin{array}{l}\text { Янтарная } \\
\text { к-та, г/дм³ }\end{array}$ & 1,11 & 1,06 & 1,15 & 1,17 & 1,17 & 1,18 & 1,17 & 1,15 & 1,20 \\
\hline $\begin{array}{l}\text { Лимонная } \\
\text { к-та, г/дм }\end{array}$ & 0,11 & 0,11 & 0,14 & 0,12 & 0,14 & 0,12 & 0,15 & 0,12 & 0,14 \\
\hline $\begin{array}{l}\text { Уксусная } \\
\text { к-та, г/дм }{ }^{3}\end{array}$ & 0,34 & 0,34 & 0,36 & 0,38 & 0,38 & 0,34 & 0,34 & 0,37 & 0,36 \\
\hline $\begin{array}{l}\text { Молочная } \\
\text { к-та, г/дм³ }\end{array}$ & 0,88 & 0,86 & 0,81 & 0,82 & 0,8 & 0,81 & 0,80 & 0,83 & 0,78 \\
\hline $\begin{array}{l}\text { Сумма } \\
\text { органических } \\
\text { кислот, г/дм³ }\end{array}$ & 6,04 & 5,78 & 5,93 & 5,87 & 5,91 & 5,98 & 6,04 & 5,90 & 5,85 \\
\hline $\begin{array}{l}\text { Сумма } \\
\text { фенольных } \\
\text { веществ, } \\
\text { мг/дм³ }\end{array}$ & 2004,7 & 1934,9 & 1911,8 & 1952,7 & 1940,6 & 1967,2 & 1923,3 & 1932,5 & 1975,8 \\
\hline $\begin{array}{l}\text { Антоцианы, } \\
\text { мг/дм }{ }^{3}\end{array}$ & 651,9 & 610,5 & 617,9 & 628 & 602,2 & 636,9 & 609,4 & 610,9 & 623,3 \\
\hline $\begin{array}{l}\text { Мономерные } \\
\text { формы, мг/дм }\end{array}$ & 888,3 & 851,8 & 856,8 & 849,2 & 847,5 & 871,8 & 861 & 850,1 & 863,7 \\
\hline
\end{tabular}


При анализе данных выявлена следующая закономерность: в контрольных и экспериментальных образцах вина с добавлением низина происходило постепенное уменьшение массовой концентрации органических кислот, связанное с этерификацией этиловым спиртом.

По массовой концентрации суммы фенольных веществ, антоцианов и мономерных форм (фенольных веществ) опытных образцов вин с добавлением низина оставались без изменений и находились на одном уровне с аналогичными показателями в контрольных образцах.

Дегустационной комиссией ФГБНУ СКФНЦСВВ в открытой дегустации были оценены органолептические свойства столовых вин, а именно контрольных и опытных образцов (табл. 3). Проходным баллом был принят балл 7,3.

Таблица 3 - Изменение органолептических показателей вина после выдержки в течение месяца в присутствии пищевой добавки низина

\begin{tabular}{|c|c|c|c|c|c|}
\hline \multirow{2}{*}{ Образец } & \multicolumn{5}{|c|}{ Органолептические показатели } \\
\hline & прозрачность & цвет & аромат & вкус & балл \\
\hline $\begin{array}{l}\text { Вино } \\
\text { столовое } \\
\text { сухое белое } \\
\text { (контроль) } \\
\end{array}$ & $\begin{array}{l}\text { Прозрачное, } \\
\text { без осадка } \\
\text { и посторонних } \\
\text { включений } \\
\end{array}$ & $\begin{array}{l}\text { Соломен- } \\
\text { ный }\end{array}$ & $\begin{array}{l}\text { Чистый, винный, } \\
\text { с цветочными } \\
\text { оттенками, соот- } \\
\text { ветствует типу }\end{array}$ & $\begin{array}{l}\text { Полный, гармо- } \\
\text { ничный, свежий, } \\
\text { без посторонних } \\
\text { оттенков }\end{array}$ & 8,3 \\
\hline $\begin{array}{l}\text {-//- то же } \\
\text { с добавкой } \\
\text { низина }\end{array}$ & $\begin{array}{l}\text { Прозрачное, } \\
\text { без осадка } \\
\text { и посторонних } \\
\text { включений }\end{array}$ & $\begin{array}{l}\text { Соломен- } \\
\text { ный }\end{array}$ & $\begin{array}{l}\text { Чистый, винный, } \\
\text { с цветочными } \\
\text { оттенками, соот- } \\
\text { ветствует типу }\end{array}$ & $\begin{array}{l}\text { Полный, гармо- } \\
\text { ничный, свежий, } \\
\text { без посторонних } \\
\text { оттенков }\end{array}$ & 8,3 \\
\hline $\begin{array}{l}\text { Вино } \\
\text { столовое } \\
\text { сухое красное } \\
\text { (контроль) }\end{array}$ & $\begin{array}{l}\text { Прозрачное, } \\
\text { без осадка } \\
\text { и посторонних } \\
\text { включений }\end{array}$ & Красный & $\begin{array}{l}\text { Чистый, винный, } \\
\text { ягодный, с оттен- } \\
\text { ками смородины, } \\
\text { чернослива } \\
\text { и терна }\end{array}$ & $\begin{array}{l}\text { Полный, уме- } \\
\text { ренно свежий, } \\
\text { с оттенками крас- } \\
\text { ных ягод в по- } \\
\text { слевкусии без по- } \\
\text { сторонних оттен- } \\
\text { ков }\end{array}$ & 8,1 \\
\hline $\begin{array}{l}\text { - /l- то же } \\
\text { с добавкой } \\
\text { низина }\end{array}$ & $\begin{array}{l}\text { Прозрачное, } \\
\text { без осадка } \\
\text { и посторонних } \\
\text { включений }\end{array}$ & Красный & $\begin{array}{l}\text { Чистый, винный, } \\
\text { ягодный, с оттен- } \\
\text { ками смородины, } \\
\text { чернослива } \\
\text { и терна }\end{array}$ & $\begin{array}{l}\text { Полный, уме- } \\
\text { ренно свежий, } \\
\text { с оттенками крас- } \\
\text { ных ягод в по- } \\
\text { слевкусии без по- } \\
\text { сторонних оттен- } \\
\text { ков }\end{array}$ & 8,1 \\
\hline
\end{tabular}


Плодоводство и виноградарство Юга России № 57(03), 2019 г.

В результате анализа экспериментальных данных установлено, что контрольные и опытные образцы имели одинаковые органолептические характеристики и дегустационный балл.

Вино столовое сухое белое характеризовалось соломенным цветом, чистым винным ароматом, с цветочными оттенками, соответствующим типу; полным, гармоничным, свежим вкусом без посторонних оттенков.

Образец столового сухого красного вина имел красный цвет, чистый, винный, ягодный аромат с оттенками смородины, чернослива и терна; полный, умеренно свежий вкус, с оттенками красных ягод в послевкусии, без посторонних оттенков. Образцы столовых вин с добавкой низина были оценены на уровне контрольных образцов, поскольку характеризовались чистым ароматом и не имели в послевкусии посторонних оттенков.

Bbыводы. Получены новые сведения о закономерностях изменения физико-химических показателей вин в ходе их хранения в присутствии антибиотиков. Выявлены закономерности изменения органолептических показателей и физико-химического состава винодельческой продукции под действием антибиотика низина.

Установлено, что в контрольных и экспериментальных образцах вина с добавлением низина все анализируемые показатели (объёмная доля этилового спирта, массовая концентрация сахаров, массовая концентрация титруемых кислот в пересчёте на винную кислоту, массовая концентрация летучих кислот в пересчёте на уксусную кислоту, массовая концентрация приведённого экстракта, массовая концентрация лимонной кислоты, массовая концентрация общего диоксида серы, органических кислот, фенольных соединений, в том числе красящих веществ для красных вин) физико-химического состава опытных образцов вин с добавлением низина оставались без изменений и находились на одном уровне с аналогичными показателями в контрольных образцах. 


\section{Литература}

1. Комплексная программа развития биотехнологий в Российской Федерации на период до 2020 года (утв. Правительством РФ от 24 апреля 2012 г. № 1853п-П8). - [Электронный ресурс]. - Режим доступа. - http://www.garant.ru/products/ipo/prime/ doc/70068244/\#ixzz5XCtzdnSs.- (дата обращения: 15.03.2019).

2. Технический Регламент Таможенного Союза 021/2011 «О безопасности пищевой продукции». - [Электронный ресурс]. - Режим доступа: http://www.eurasiancommission.org/ru/act/texnreg/deptexreg/tr/Documents/TR\%20TS\%20Pi shevayaProd.pdf.

3. Технический регламент таможенного союза ТР ТС 029/2012 «Требования безопасности пищевых добавок, ароматизаторов и технологических вспомогательных средств». Принят решением Совета Евразийской экономической комиссии от 20 июля 2012 г. № $58.308 \mathrm{c}$.

4. Natamycin Issue. - [Электронный pecypc]. - Режим доступа. - http://www.winetech.co.za/documents/docs2010/NatamycinNewsletter.pdf. - (дата обращения: 18.11.2018).

5. Alberts, P. Development of a Fast, Sensitive and Robust LC-MS/MS Method for the Analysis of Natamycin in Wine / P. Alberts, M.A. Stander, A. de Villiers // South African Journal for Enology and Viticulture. - V. 32. - N. 1. - 2011. - P. 51-59.

6. Antimicrobials in food / edited by P. Michael Davidson, John N. Sofos, A.L. Branen. - 3rd ed. - 721p.

7. Veeresh, J. Microbial production of bacteriocins: Latest research development and applications / Veeresh J., Jin C. W. // Biotechnology Advances. - V. 36. - № 8. - 2018. P. 2187-2200.

8. Sun, X. Detection method optimization, content analysis and stability exploration of natamycin in wine / X. Sun and el. // Food Chemistry. - V. 194. - 2016. - P. 928-937.

9. Антоненко М.В., Гугучкина Т.И., Гапоненко Ю.В., Абакумова А.А. Теоретическое обоснование и разработка методики определения консервантов микробиального происхождения в винодельческой продукции [Электронный ресурс] // Плодоводство и виноградарство Юга России. 2015. № 34(4). С. 143-152. URL: http://journalkubansad.ru/pdf/15/04/13.pdf. (дата обращения: 09.04.2019).

10. Абакумова А.А., Антоненко М.В., Гугучкина Т.И. Метод определения антибиотиков в вине // Наука Кубани. 2018. № 2. С. 10-15.

11. Разработка практических рекомендаций и алгоритма контроля низина в винодельческой продукции / М.В. Антоненко, Т.И. Гугучкина, А.А. Абакумова, О.П. Антоненко // Инновации в индустрии питания и сервисе: матер. III межд. науч. практ. конф., посвящённой 100-летию ФГБОУ ВО «Кубанский государственный технологический университет» (25 октября 2018 года). Краснодар: КубГТУ, 2018. С. 345-352.

12. Идентификация антибиотиков в виноделии и способы их удаления / А.А. Абакумова, Т.И. Гугучкина, М.В. Антоненко, Н.М. Агеева, А.Н. Тихонова // Инновации в индустрии питания и сервисе: матер. III межд. науч. практ. конф., посвящённой 100-летию ФГБОУ ВО «Кубанский государственный технологический университет» (25 окт. 2018 года). Краснодар: КубГТУ, 2018. С. 434-436.

13. Методы контроля качества и безопасности винодельческой продукции. Методические рекомендации / Т.И. Гугучкина, М.Г. Марковский, М.В. Антоненко, К.В. Резниченко, Б.В. Бурцев, А.А. Абакумова. Краснодар: ФГБНУ СКФНЦСВВ, 2018. 59 c. 
14. Radler, E. Possible Use of Nisin in Winemaking. I. Action of Nisin Against Lactic Acid Bacteria and Wine Yeasts in Solid and Liquid Media / E. Radler // Am. J. Enol. Vitic. 1990. - V. 41. - №. 1. - P. 1-6.

15. Soliman, L. C. Method development for sensitive determination of nisin in food products by micellar electrokinetic chromatography / L. C. Soliman, K. K. Donkor // Food Chemistry. - 2010. - V. 119. - P. 801-805.

16. Способ определения натамицина методом капиллярного электрофореза: патент RU 2018102766 А / Абакумова, А.А., Гугучкина Т.И., Марковский М.Г., Антоненко M.В.; заявл. 15.03.2018; опубл. 17.10.2018

17. Kvasnička, F. Electrophoretic determination of histamine / F. Kvasnička, S. Kavková, A. Honzlová // Journal of Chromatography A. - V. 1588. - 2019. - P. 180-184.

18. Fabjanowicz, M. Detection, identification and determination of resveratrol in wine. Problems and challenges / M. Fabjanowicz, J. Płotka-Wasylka, J. Namieśnik // Trends in Analytical Chemistry. - V. 103. - 2018. - P. 21-33.

19. Kamiloglu, S. Authenticity and traceability in beverages / S. Kamiloglu // Food Chemistry. - V. 277. - 2019. - P. 12-24.

20. Le, T.H.H. Screening determination of food additives using capillary electrophoresis coupled with contactless conductivity detection / T.H.H. Le, T.Q.H. Nguyen, C.S. Tran, T.T. Vu, T.L. Nguyen, V.H. Cao, T.D. Mai // Food Control. - V. 77. - 2017. - P.281-289.

21. ГОСТ Р 52841-2007 Продукция винодельческая. Определение органических кислот методом капиллярного электрофореза. М.: Изд-во стандартов. 2006. 12 с.

\section{References}

1. Kompleksnaya programma razvitiya biotekhnologij v Rossijskoj Federacii na period do 2020 goda (utv. Pravitel'stvom RF ot 24 aprelya 2012 g. № 1853p-P8). - [Elektronnyj resurs]. $\quad-$ Rezhim dostupa. - http://www.garant.ru/products/ipo/prime/ doc/70068244/\#ixzz5XCtzdnSs.- (data obrashcheniya: 15.03.2019).

2. Tekhnicheskij Reglament Tamozhennogo Soyuza 021/2011 «O bezopasnosti pishchevoj produkcii». - [Elektronnyj resurs]. - Rezhim dostupa: http://www.eurasiancommission.org/ru/act/texnreg/deptexreg/tr/Documents/TR\%20TS\%20PishevayaProd.pdf.

3. Tekhnicheskij reglament tamozhennogo soyuza TR TS 029/2012 «Trebovaniya bezopasnosti pishchevyh dobavok, aromatizatorov i tekhnologicheskih vspomogatel'nyh sredstv». Prinyat resheniem Soveta Evrazijskoj ekonomicheskoj komissii ot 20 iyulya 2012 g. № 58.308 s.

4. Natamycin Issue. - [Elektronnyj resurs]. - Rezhim dostupa. - http://www.winetech.co.za/documents/docs2010/NatamycinNewsletter.pdf. - (data obrashcheniya: 18.11.2018).

5. Alberts, P. Development of a Fast, Sensitive and Robust LC-MS/MS Method for the Analysis of Natamycin in Wine / P. Alberts, M.A. Stander, A. de Villiers // South African Journal for Enology and Viticulture. - V. 32. - N. 1. - 2011. - P. 51-59.

6. Antimicrobials in food / edited by P. Michael Davidson, John N. Sofos, A.L. Branen. - 3rd ed. - 721p.

7. Veeresh, J. Microbial production of bacteriocins: Latest research development and applications / Veeresh J., Jin C. W. // Biotechnology Advances. - V. 36. - № 8. - 2018. P. 2187-2200. 
8. Sun, X. Detection method optimization, content analysis and stability exploration of natamycin in wine / X. Sun and el. // Food Chemistry. - V. 194. - 2016. - P. 928-937.

9. Antonenko M.V., Guguchkina T.I., Gaponenko Yu.V., Abakumova A.A. Teoreticheskoe obosnovanie i razrabotka metodiki opredeleniya konservantov mikrobial'nogo proiskhozhdeniya $\mathrm{v}$ vinodel'cheskoj produkcii [Elektronnyj resurs] // Plodovodstvo i vinogradarstvo Yuga Rossii. 2015. № 34(4). S. 143-152. URL: http://journalkubansad.ru/pdf/15/04/13.pdf. (data obrashcheniya: 09.04.2019).

10. Abakumova A.A., Antonenko M.V., Guguchkina T.I. Metod opredeleniya antibiotikov v vine // Nauka Kubani. 2018. № 2. S. 10-15.

11. Razrabotka prakticheskih rekomendacij $\mathrm{i}$ algoritma kontrolya nizina $\mathrm{v}$ vinodel'cheskoj produkcii / M.V. Antonenko, T.I. Guguchkina, A.A. Abakumova, O.P. Antonenko // Innovacii v industrii pitaniya i servise: mater. III mezhd. nauch. prakt. konf., posvyashchyonnoj 100-letiyu FGBOU VO «Kubanskij gosudarstvennyj tekhnologicheskij universitet» (25 oktyabrya 2018 goda). Krasnodar: KubGTU, 2018. S. 345-352.

12. Identifikaciya antibiotikov v vinodelii i sposoby ih udaleniya / A.A. Abakumova, T.I. Guguchkina, M.V. Antonenko, N.M. Ageeva, A.N. Tihonova // Innovacii v industrii pitaniya i servise: mater. III mezhd. nauch. prakt. konf., posvyashchyonnoj 100-letiyu FGBOU VO «Kubanskij gosudarstvennyj tekhnologicheskij universitet» (25 okt. 2018 goda). Krasnodar: KubGTU, 2018. S. 434-436.

13. Metody kontrolya kachestva i bezopasnosti vinodel'cheskoj produkcii. Metodicheskie rekomendacii / T.I. Guguchkina, M.G. Markovskij, M.V. Antonenko, K.V. Reznichenko, B.V. Burcev, A.A. Abakumova. Krasnodar: FGBNU SKFNCSVV, 2018. 59 s.

14. Radler, E. Possible Use of Nisin in Winemaking. I. Action of Nisin Against Lactic Acid Bacteria and Wine Yeasts in Solid and Liquid Media / E. Radler // Am. J. Enol. Vitic. 1990. - V. 41. - №. 1. - P. 1-6.

15. Soliman, L. C. Method development for sensitive determination of nisin in food products by micellar electrokinetic chromatography / L. C. Soliman, K. K. Donkor // Food Chemistry. - 2010. - V. 119. - P. 801-805.

16. Sposob opredeleniya natamicina metodom kapillyarnogo elektroforeza: patent RU 2018102766 A / Abakumova, A.A., Guguchkina T.I., Markovskij M.G., Antonenko M.V.; zayavl. 15.03.2018; opubl. 17.10.2018.

17. Kvasnička, F. Electrophoretic determination of histamine / F. Kvasnička, S. Kavková, A. Honzlová // Journal of Chromatography A. - V. 1588. - 2019. - P. 180-184.

18. Fabjanowicz, M. Detection, identification and determination of resveratrol in wine. Problems and challenges / M. Fabjanowicz, J. Płotka-Wasylka, J. Namieśnik // Trends in Analytical Chemistry. - V. 103. - 2018. - P. 21-33.

19. Kamiloglu, S. Authenticity and traceability in beverages / S. Kamiloglu // Food Chemistry. - V. 277. - 2019. - P. 12-24.

20. Le, T.H.H. Screening determination of food additives using capillary electrophoresis coupled with contactless conductivity detection / T.H.H. Le, T.Q.H. Nguyen, C.S. Tran, T.T. Vu, T.L. Nguyen, V.H. Cao, T.D. Mai // Food Control. - V. 77. - 2017. - P.281-289.

21. GOST R 52841-2007 Produkciya vinodel'cheskaya. Opredelenie organicheskih kislot metodom kapillyarnogo elektroforeza. M.: Izd-vo standartov. 2006. 12 s. 